\title{
Research on the Difference Between Accounting System and Tax Laws
}

\author{
Yi Sun \\ Liaoning Economic Vocational Technology Institute, Liaoning Shenyang, 110122 \\ mazda525@126.com
}

\begin{abstract}
The article analyzes and demonstrates the differences between China's accounting system and tax laws, and the difference between accounting system and tax law in China has its deep historical background, Its main reason lies in the difference between objective of accounting system and goal of tax law, but the widening gap has brought about adverse effects on both the tax and ratepaying. The analysis shows that the difference between accounting system and tax law is coordination, the coordination between should follow certain principles promoted from two aspects of accounting system and tax law, so as to promote the further improvement of accounting system and tax law.
\end{abstract}

Keywords: Accounting system; Tax law; Coordinate difference.

\section{Introduction}

The relationship between accounting system and tax laws has attracted more and more attention by people. To deal with the relationship between accounting system and tax laws and regulations is not only the important work of the tax department and the enterprise, but also has great influence on the development of national economy. How to properly deal with the relationship between accounting system and tax laws and regulations, it is not only the theoretical problems of accounting system and tax system, but also it is the practical problem that determine by tax and tax levy and reflect the accounting information. In China's planned economy period, the accounting system is guided by tax laws and regulations, emphasizing that accounting should be attached to laws such as finance and taxation. With the establishment and improvement of China's market economy system and the process of economic globalization, the accounting system and the tax laws in China have also been greatly reform. In the new accounting system and tax laws, the principles of relative independence and proper separation of the accounting and tax regulations are reflected. The separation of accounting system and tax laws is necessary, but the difference formed by the gap between accounting and tax law, on the one hand it increase the taxpayer's financial accounting cost, on the other hand, it is not conducive to the collection and management of tax collection agency. Therefore, how to coordinate the differences between accounting system and tax laws is very important.

\section{Analysis of the specific differences between accounting system and tax law}

\subsection{Analysis of differences in income recognition}

Income is an important subject of accounting, and also an important item of tax law. For accounting, finally, profits form profits and reflect the business results of enterprises; for tax revenue, whether it is turnover tax or income tax, the calculation and collection process need to be based on income.

The newly revised accounting standards define the income as the total inflow of economic interests which is caused by the increase in owners' equity and the capital invested by the owners in the daily activities. But the tax law does not give a general definition of income, the tax law often refers to taxable income, and the related concepts include sales, turnover, and total income and so on. The tax law strictly defines its connotation around different concepts. From a general perspective, the meaning of income in tax law is much wider than that in accounting. The different functions and objectives determine their significant differences in terms of revenue recognition.

\subsection{Analysis of differences in deductions}

The deduction item is the item deducted from the gross income when calculating the taxable income, it refers to the costs, expenses, taxes and losses related to taxpayers. From theoretically speaking, all necessary normal expenses for enterprises to obtain operating income should be deducted, 
so we can determine net income, however tax laws are often limited by terms of deductions and time. All these restrictions are to ensure the state's revenue and prevent tax avoidance. It reflects the goal orientation and policy orientation of tax law and accounting system.

\subsection{Analysis of difference between assets handling}

The asset is one of the most important accounting elements, refers to the enterprise caused by past transactions or events, owned or controlled by enterprises, is expected to bring economic benefits to the enterprise resources. These three basic characteristics are the basis for accounting and tax treatment of assets. The difference between accounting system and tax law in asset handling involves assets recognition, valuation, value transfer and disposal of assets.

\subsection{Analysis of difference in investment treatment}

The newly revised accounting standards have made great revisions in investment, and have carried out new regulations and classifications for investment business. "Accounting standards for enterprises - long-term equity investment" specify long-term equity investment business, "accounting standards for enterprises - recognition and measurement of financial instruments" to standardize enterprise financial assets, the corresponding accounting also changed greatly.

\subsection{Analysis of the difference between non-monetary assets exchange}

The exchange of non-monetary assets, refers to the exchange transaction of inventory, fixed assets, intangible assets and long-term equity investments and other non-monetary assets. The basic principle of tax law dealing with non-monetary assets exchange is to deal with two independent transactions, and the income from the transfer of assets is subject to income tax. In addition, the tax law has a special transfer pricing rules for unfair related party non-monetary transactions, the transactions do not meet the principle of independent transaction price can be adjusted according to a specified method. After implementation of new guidelines, the remaining differences will be mainly the exchange tax gap and discrepancy arising from the measurement of assets in book value.

In particular, those accounting standards find no commercial substance, but tax laws identify tax avoidance purposes. It is likely to be the main source of the tax discrepancy.

\subsection{Analysis of the difference of debt restructuring}

The difference of tax revenue caused by debt restructuring business reflects some basic principles of tax law in dealing with this business. One is the principle that the income is correspond to loss principle. The tax law recognizes the creditor has abandoned part of the debt that be as a loss, which shall be included in the current profits and losses. Correspondingly, the debtor's exempted debt is a free gain, and should be recognized as revenue and tax. The second is the principle of anti-tax avoidance. In order to prevent the transfer of profits through debt restructuring between related parties, tax laws specially formulated relevant provisions to evade taxes.

\section{The background difference between accounting system and tax law}

\subsection{The different goals of accounting system and tax law}

The goal of accounting system is to give the corresponding standards and guidelines of accounting confirmation, measurement, record and report, to ensure that the enterprise for the users provide the true financial information. The fundamental point of our accounting system should still be to provide investors with useful information to understand the authenticity and profitability of corporate assets. The goal of tax law is to ensure the revenue of the state, and then use tax leverage to carry out macroeconomic regulation and control. The tax law follows the principle of beneficence, which requires that the formulation and implementation of the tax law will help to obtain financial revenue in full and help to give full play to the role of economic leverage. It can be seen that the accounting system and the tax law are two completely different systems in terms of objectives. Because of the different objectives of accounting system and tax law, this leads to different norms and requirements for the same economic matters or behaviors.

\subsection{The assumptions of accounting system and tax law are different}

The four basic assumptions of accounting include: accounting entity, continuous operation, accounting staging, and monetary measurement. The determination of accounting objects, the choice of accounting methods, and the collection of accounting data are all based on the basic assumptions of accounting. Because of the difference between accounting system and tax law objectives, there are differences between them in following these assumptions.

\subsection{The accounting system is different from the principle of tax law}

Because of the different goals, the principles followed must be quite different. Whether accounting or tax collection, principles will determine the choice of methods, or even the basis for career judgment. Differences in principle will lead to differences in accounting system and tax law in dealing with business and judging basis. In fact, the basic principles of the accounting system and the tax law have in common, the basic principles of tax law according to the 
accounting law but preservation tax and reflect the policy guidance based on the requirements of the tax law and accounting system diverge in some basic principles.

\section{Coordination principles and suggestions for difference between the accounting system and the tax law}

China's accounting system and the tax law difference has its profound historical background and theory origin, because of the economic relationship between accounting system and tax code, this kind of contradiction is objective and inevitable. However, from the current situation of our country, this contradiction is not irreconcilable. We emphasize their independence, emphasizing both the excessive separation, which will produce strong negative effects. The key to solve the problem need correct principles, coordinate the relationship each other, and strive to not only improve the accounting system, maintain the fairness and the authority of tax law, but also we make the theory on development and practical.

\subsection{The accounting system should be actively coordinated with tax law}

(1) The perfection accounting system should be consider the coordination problem with tax law

The coordination of accounting system and tax law is a mutual and two-way process. The reform of accounting system and the revision of tax law are often in succession. However, the reform of accounting system should be carried out one step ahead. Therefore, the accounting system must pay attention to the information demand of tax regulation and consider the coordination with tax law. Especially in China's market economy is still underdeveloped, accounting information still bear the macroeconomic management service functions, service tax is one of them.

(2) Increase the disclosure of tax related information

There are relatively few information about tax (income tax) disclosed by Listed Companies in China. Lack of disclosure and non - disclosure of tax return form, this makes shareholders, creditors and other stakeholders unable to fully understand the information related to tax collection, they cannot understand the difference between accounting profits and taxable income. The non disclosure of tax information also faces great obstacles to study the relationship between book-tax, the coordination of accounting system and tax law is difficult to further study, which is not conducive to effectively coordinating and reducing tax differences.

(3) Narrowing the scope of accounting policy without damaging the quality of accounting information

The accounting system can minimize the selection scope of accounting policy, regulate the adjustment method between accounting earnings and taxable income, and simplify the calculation of taxes, but the premise is not to damage the quality of accounting information, and does not affect the realization of accounting objectives.

\subsection{The tax law should be coordinated with the accounting system}

(1) The government should revise and improve the existing tax law system to minimize unnecessary differences.

Our existing tax system is very complex, including the formulation of the National People's Congress and its Standing Committee of tax laws and tax administrative regulations formulated by the State Council and local tax regulations and tax department regulations etc. Among them, there are many factors that affect the accounting of enterprises. It is necessary for the tax department to clean up and examine the existing tax laws and regulations. As long as it has little impact on tax revenue, or there is no major obstacle to policy implementation and tax collection and management, the relevant provisions of the tax law should be harmonized with the accounting system as far as possible to reduce unnecessary differences as far as possible.

(2) The government issued relevant guide to tax adjustment

When the State Administration of Taxation or the provinces, autonomous regions and municipalities directly under the central government promulgate the relevant tax laws and regulations, the article suggests that effect to the enterprise accounting should refer to the Ministry of Finance issued accounting practices, issued the relevant tax adjustment guide, guide the actual accounting, tax accounting and tax adjustment etc..

(3) Appropriately relax restrictions on the choice of accounting methods for enterprises.

With the increasingly fierce market competition and the acceleration of technological progress,

The wear and tear of the fixed assets in the physical form and the technical and intangible wear has increased rapidly. The accounting system has given more choices in terms of depreciation years and depreciation methods, from the perspective of enterprises, from the viewpoint of capital preservation, they prefer to shorten the depreciation years and adopt accelerated depreciation methods. As the choice of tax policy restricting enterprise accounting policy, its purpose is to prevent enterprises from making use of accounting policies to achieve the purpose of evasion or delay in tax payment.

\section{Conclusions}

The generation of tax differences involves many accounting operations, and the handling is complicated. But through the analysis of this article, we can draw the conclusion that the difference between tax system and tax law is different from tax law in terms of objectives, assumptions and principles. The most fundamental reason is the separation of the two objectives under market economy. From the reality of our country, it is the best choice to keep the differences between tax system and tax law in a moderate range and coordinate them. At present, from the two aspects of accounting system and tax law, the government should eliminate unnecessary differences and 
establish effective coordination mechanism between the main body of legislation.

\section{References}

1. Shen Chang-e. The model of developed country tax Association for our country [J]. Finance and accounting monthly, 2001 (2): 18-24.

2. Dai Deming, Zhang Yan, He Yurun. Research on the cooperation between accounting system and tax law in China --- Based on the relationship between Tax Association and the two differences [J]. Accounting Research, 2005, 1: 50-56.
3. Li Jianfa, Zhang Jinjin, Zhang Guoqing, Zhao Junying. Research on the implementation mechanism of government accounting standards based on institutional theory [J]. Accounting Research. 2017-02-15: 3-8.

4. Wang Wanting. Discussion on accounting of institutions under the new institution accounting system [J]. Accounting Learning, 2017, 033: 10-13.

5. Zhou Leifang. Research on accounting problems of public welfare institutions [D]. Jiangxi University of Finance and Economics, 2017, 06.

6. Qian Ye. The effect of accounting conservatism on enterprise investment efficiency [D]. Guangdong University of Finance \& Economics, 2017, 5. 